\title{
Peran Pesantren dalam Penyebarluasan Seni Kaligrafi Islam di Jawa Barat
}

\author{
Ading Kusdiana \\ Jurusan Sejarah dan Peradaban Islam UIN Bandung \\ Jln. A.H. Nasution No. 105 Bandung
}

\begin{abstract}
This paper discusses a description of the role of pesantren in West Java in the dissemination of the art of Islamic calligraphy. The purpose of the research is to find out the development history of the art of Islamic calligraphy and the role of pesantren located in West Java in disseminating it. The method which is used in the research is historical research method. The result of the research shows that the art of Islamic calligraphy not only appeared in the Arabian Peninsula but also expanded to West Java. Pesantren, as one of Islamic activity centres, has a big role in disseminating the art of Islamic calligraphy. Pesantren is associated with the amount of interest, attention, and support provided by Kyai, head of pesantren, to develop the art of calligraphy through educational activities, ranging from reading and writing Quran, teaching activities, including preserving the art of Islamic calligraphy.
\end{abstract}

Keywords: calligraphy, pesantren, dissemination, West Java

\begin{abstract}
ABSTRAK
Tulisan ini membahas deskripsi tentang peran pesantren di Jawa Barat dalam penyebaran seni kaligrafi Islam. Tujuan dari penelitian ini ialah untuk mengetahui tentang sejarah perkembangan seni kaligrafi Islam dan peran pesantren yang ada di Jawa Barat dalam penyebarannya. Metode yang digunakan dalam penelitian ini adalah metode sejarah. Hasil penelitian menunjukkan bahwa seni kaligrafi Islam tidak hanya muncul di Semenanjung Arab, tetapi juga meluas hingga ke Jawa Barat. Pesantren, sebagai salah satu pusat kegiatan agama Islam, memiliki peran besar dalam menyebarkan seni kaligrafi Islam tersebut. Pesantren berkaitan dengan sejumlah kepentingan, perhatian, dan dukungan yang diberikan oleh Kyai, kepala pesantren, untuk mengembangkan seni kaligrafi melalui kegiatan-kegiatan pendidikan, mulai dari membaca dan menulis Quran, kegiatan pengajaran, termasuk pelestarian seni kaligrafi Islam.
\end{abstract}


Kata kunci: kaligrafi, pesantren, penyebaran, Jawa Barat

\section{PENDAHULUAN}

Saat ini seni kaligrafi Islam merupakan bentuk seni budaya Islam yang menjadi aset budaya Islam yang utama. Kehadirannnya menempati posisi yang sangat penting, karena dibangun di atas norma-norma keindahan yang luar biasa. Seni ini acapkali disebut sebagai seni rupa Islam yang mengeksplorasi tulisan Arab menjadi tulisan yang indah dipandang.

Penulisan kaligrafi Islam dapat dipandang sebagai salah satu bentuk apresiasi seniman muslim terhadap keindahan Al-Quran, sehingga dengan kedudukannya yang tinggi, seni kaligrafi Islam telah memperlihatkan semangat Islam (izzah al-islamiyah) yang sangat istimewa. Dengan demikian tidak mengherankan jika seni kaligrafi Islam sering disebut sebagai the art of Islamic (seninya seni Islam). Apa yang tertulis dalam kaligrafi Islam pada substansinya merupakan pintu bagi suatu bangsa untuk memasuki sebuah peradaban baru yaitu peradaban Islam.

Diskursus tentang kemunculan dan penyebaran seni kaligrafi Islam dapat dipastikan muncul pertama kali dengan hadirnya Islam itu sendiri dengan seperangkat instrumennya di kawasan Jazirah Arab. Selanjutnya dari kawasan ini secara perlahan-lahan tetapi pasti menyebar ke berbagai kawasan dunia Islam lain, seperti kawasan Afrika Utara, Asia Tengah, Asia Selatan, hingga kawasan Asia Tenggara, tidak terkecuali sampai ke Indonesia, bahkan berkembang di Jawa Barat.

Agama Islam masuk ke Indonesia sejak abad ke-7 Masehi dan mulai menyebar ke wilayah Jawa Barat pada abad ke-14 Masehi. Dengan masuk 
dan menyebarnya Islam ke sebuah daerah, dapat dikatakan bahwa dari sinilah awal mula terbentuknya cikal bakal komunitas muslim. Selanjutnya setelah terbentuknya cikal bakal komunitas Muslim, hampir semua corak seni budaya masyarakat Arab mempengaruhi budaya Indonesia, yang mencakup semua aspek bentuk kesenian, baik seni suara, musik, sastra, lukis, arca, tari, drama, arsitektur, seni kaligrafi dan lain-lain (Kamsidjo, 2012: 1; Ekadjati, 1984: 89).

Sartono Kartodirdjo et al. (1976: 124-127) mengemukakan bahwa agama Islam masuk dan berkembang ke Indonesia melalui saluran kesenian dan pendidikan. Ada beberapa kesenian yang dijadikan sebagai sarana islamisasi seperti seni gamelan, wayang, sani sastra, seni rupa dan seni kaligrafi . Kesenian-kesenian tersebut banyak dipertunjukkan di Yogyakarta, Solo, Cirebon, dan lain-lain. Pertunjukan seni gamelan ini dapat mengundang masyarakat untuk berkumpul dan selanjutnya dilaksanakan dakwah keagamaan. Di samping seni gamelan, terdapat juga pertunjukkan seni wayang yang sangat digemari oleh masyarakat. Biasanya dengan melalui cerita-cerita wayang itulah para ulama menyisipkan pesan ajaran agama Islam, sehingga masyarakat dapat dengan mudah menangkap dan memahaminya. Sebagai contohnya, Sunan Kalijaga memanfaatkan seni wayangnya untuk proses Islamisasi. Selain itu, saluran Islamisasi juga berkembang melalui seni kaligrafi di mana melalui lembaga pendidikan pesantren biasanya seorang kiyai mengajari santrinya bagaimana cara menulis khat Arab.

Perlu diketahui bahwa penyebarluasan seni kaligrafi Islam di Jawa Barat tidak bisa dilepaskan dari keberadaan pesantren sebagai lembaga pendidikan yang telah ada pada waktu itu. Bersamaan dengan terbentuknya cikal bakal muslim yang diikuti dan masuknya semua corak seni budaya masyarakat 
Arab Islam ke wilayah Jawa Barat, ternyata di wilayah Jawa Barat sudah banyak berdiri pesantren sebagai lembaga pendidikan keagamaaan tradisional yang memiliki peran yang besar di dalam menyebarluaskan seni kaligrafi.

Terkait dengan permasalahan tentang seni kaligrafi Islam dan peran pesantren tersebut, muncul persoalan yang dirumuskan dalam pertanyaaanpertanyaan sebagai berikut: Bagaimana sejarah kemunculan seni kaligrafi di Dunia Islam? Bagaimana pesantren berperan dalam penyebarluasan seni kaligrafi Islam di Jawa Barat? Pesantren-pesantren di Jawa Barat yang mana yang memiliki peran dalam penyebarluasan seni kaligrafi?

Tulisan ini bertujuan untuk menjawab persoalan-persoalan tersebut. Oleh karena penelusuran informasi yang dilakukan jauh ke belakang, hingga abad ke-7 M., maka metode yang dipergunakan dalam penelitian ini adalah metode penelitian sejarah yang dilakukan melalui tahapan heuristik, kritik, interpretasi dan historiografi.

\section{PEMBAHASAN}

\section{Sejarah Kemunculan Seni Kaligrafi}

Secara etimologis kata kaligrafi berasal dari bahasa Yunani Colios yang berarti indah dan graphia yang berarti tulisan. Dalam bahasa Arab, seni ini diistilahkan dengan khatt (seni menulis hurup Arab atau tulisan atau garis) yang indah (al-kitabah al-jamilah atau al-khatt al-jamil). Sementara orang yang memiliki keahlian menulis hurup Arab yang halus dan indah disebut $\mathrm{Al}$ Khathath. Bentuk tulisan dalam kaligrafi biasanya tidak untuk dibaca secara cepat. Hal ini karena dalam membuat kaligrafi membutuhkan konsentrasi tinggi dalam waktu lama (Triyanto, 1988: 64). 
Dasar penulisan kaligrafi Arab sebenarnya diambil dari tulisan hieroglif dari Mesir. Kemudian, seni tulisan ini terpecah menjadi Khatt Feniqi (Fenisia), kemudian tersegmentasi lagi ke dalam Al-Rhami (Aram), dan Musnad (kitab yang memuat segala macam hadits) dengan beragam bentuknya seperti $\mathrm{Al}$ Shafawi, Al-Tsamudi dan Al-Lihyani yang tersebar di wilayah Jazirah Arab bagian utara dan Al-Himyari yang tersebar di wilayah Jazirah Arab bagian selatan(Al-Iskandari dan Anami, 1961: 34; Safadi, 1979: 7-9; Israr, 1985: 33-38).

Menurut al-Maqrizi, seorang ahli sejarah abad ke-4, tulisan kaligrafi Arab pertama kali dikembangkan masyarakat Himyar, masyarakat yang mendiami semenanjung Arab bagian barat daya pada sekitar 115-525 S.M. Musnad merupakan kaligrafi Arab kuno yang mula-mula berkembang dari sekian banyak jenis khatt yang dipakai masyarakat Himyar. Dari tulisan tua Musnad yang berkembang di Yaman, lahirlah khatt Kufi . Sementara dari Al-Khat alRhami timbul Al-Khat al-Nabathi dan Al-Suryani (Al-Iskandari dan Anami, 1961: 34; Israr, 1985: 33-35; Safadi, 1979: 10-13).

Kaligrafi timbul sebagai seni digunakan untuk mengekspresikan keharmonian dan emosi melalui bentuk-bentuk huruf. Sekalipun di antara kita tidak memahami apa yang dituliskan oleh sang kaligrafer, kita dapat menikmati keindahan setiap goresan huruf yang ditorehkan menjadi bentuk-bentuk yang indah. Sebagai contoh dalam kebudayaan Cina sudah lama mengenal seni kaligrafi ini, dan biasanya yang dituliskan adalah puisi ataupun kata-kata hikmah dari para filosof di zamannya. Begitu juga dengan masyarakat Jepang dan Korea, mereka mengembangkan seni kaligrafi yang diadopsi dari seni kaligrafi Cina. Di Eropa seni kaligrafi berkembang untuk keperluan penulisan Injil (Al-Iskandari dan Anami, 1961: 60). 
Di dunia Islam kaligrafi terutama berkembang karena ada larangan melukis bentuk-bentuk mahluk hidup (binatang dan manusia). Objek kaligrafi para kaligrafer muslim adalah ayat-ayat Al Quran. Dengan demikian seni kaligrafi di dunia Islam turut membantu terpeliharanya ayat-ayat Allah. Namun di kemudian hari, ketika kekuasaan Islam hampir runtuh dan pelaksanaan norma-norma Islam semakin longgar, di Dunia Islam, dengan dipelopori kaligrafer-kaligrafer Turki muncul bentuk-bentuk binatang dalam seni kaligrafi yang disebut zoomorphic calligraph (Safadi, 1979: 41-42).

\section{Seni Kaligrafi di Dunia Islam, Indonesia, dan Jawa Barat}

Sejarah kemunculan dan perkembangan kaligrafi di Dunia Islam sinkron dengan lahir dan berkembangnya ajaran Islam di Arab. Ismail R. AlFaruqi dan Louis Lamya Al-Faruqi (1998: 391) mengatakan bahwa pada awal ketujuh Masehi berdasarkan jejak-jejak peninggalan paleografis membuktikan bahwa orang-orang Arab pada masa itu telah memiliki pengetahuan tentang seni tulis. Kemudian pada masa Rasulullah dan Khulafaurasyidin, corak kaligrafi banyak dihubungkan dengan nama tempat tulisan yang dipakai seperti Makki (Tulisan Mekkah), Madani (Madinah), Hejazi (Tulisan Hijaz) Anbari (Tulisan Anbar), Hiri (Hirah), dan Kuffi (Tulisan Kuffah). Pada periode ini corak kaligrafi Kuffi merupakan satu-satunya kaligrafi yang menjadi trend untuk menulis mushaf al-Quran(Israr, 1985: 47; Al-Baba, 1992: 15-16; ).

Pada periode Umayah khat Kuffi mulai banyak ditinggalkan. Jenis khat yang banyak dipakai pada periode ini adalah Tumar, Jalil, Nisf, Sulus, dan Sulusain. Dari berbagai jenis khat, ada tiga gaya utama yang berhubungan dengan tulisan yang dikenal di Mekkah dan Madinah yaitu Mudawwar (bundar), Mutsallats (segitiga), dan Ti'im (kembar yang tersusun dari segitiga 
dan bundar). Dari tiga gaya penulisan tersebut, gaya Kursif, gaya Muqawwar dan gaya Mabsut merupakan gaya yang banyak diutamakan. Di antara kaligrafer Bani Umayah yang termashur mengembangkan tulisan Kursif ialah Qutbah al-Muharrir yang menemukan empat tulisan yaitu Thumar, jalil, Nisf dan Tsulust (Siradjudin Ar., 1985: 78-80)

Menurut D. Siradjudin Ar. (1985: 81-84) pada masa Kekhilafahan Abbasiyah seni khat telah mencapai masa keemasannya. Pada periode ini selain gaya dan teknik menulis kaligrafi terus berkembang, para kaligrafer Kekhilafahan Abbasiyah banyak menggali penemuan-penemuan baru atau atau mendeformasi corak-corak yang berkembang. Begitu juga berkat besarnya dukungan dari khalifah dan perdana menteri para periode ini telah mendorong munculnya kaligrafer-kaligrafer terkenal seperti Ad-Dahak Ibnu Ajlam, Ishak Ibnu Muhammad, Ibnu Muqlah, Muhammad Ibnu As-Simsimani dan Muhammad Ibnu Asad, Ibnu bawwab, dan Yaqut al-Mustasimi (Al-Baba, 1992: 15-16).

Meskipun lahir di Arab, kaligrafi berkembang juga di wilayah Islam lainnya seperti Andalusia, Iran, Irak, Turki dan juga Indonesia. Di Andalusia berkembang tulisan Maghribi dan Khufu Barat dengan cabang-cabangnya khat Qairawani, Andalusi, Fasi, dan Sudani. Pada masa Dinasti Ilkhan, Timuriyah dan Safawiyah di wilayah Iran, Irak, dan Turki berkembang gaya tulisan Farisi Ta'liq, Gubar, jail, Anjeh Ta'liq, Sikasteh, Sikasteh Ta'liq, Tahriri, Gubari Ta'liq, Diwani dan Diwani Jali, Gulzar, Tugra, dan Zul I Rus. Di India sendiri pada masa Dinasti Mughal muncul khat Behari, Kufi Herati, Naskhi India dan Sulus India (Safadi, 1979: 21-23; Siradjudin Ar., 1985: 122, 129-135, 142-145).

Sebagaimana yang terjadi di awal lahirnya peradaban Islam, sejarah kaligrafi di Indonesia juga tak lepas dari sejarah masuk dan berkembangnya 
Islam di Nusantara. Di Indonesia gaya Kuffi banyak terdapat di berbagai makam kuno yang memuat lafadz-lafadz basmalah, syahadat dan shalawat nabi.

Menurut Ambary (1998: 45) berdasarkan penelitian arkelogis tulisan kaligrafi telah menjadi penanda masuknya Islam di Nusantara. Pada nisannisan yang menjadi objek kajian arkeologis tersebut banyak ditemukan berbagai model seni tulis kaligrafi, di antaranya kaligrafi dengan gaya tulisan Kuffi, Tsulutsi, Nasta'liq, bahkan kontemporer. Ia menemukan bukti tersebut pada nisan makam-makam kuno seperti di kerajaan Islam Aceh, makam Troloyo Mojokerto, Kraton Cirebon, Ternate, Jawa, Madura serta wilayah di Indonesia lainnya.

Seni kaligrafi Islam nusantara, selain pada makam atau nisan, banyak ditulis pada media lain seperti daluang, kertas, lontar, kayu, logam, kaca, bahkan karya kaligrafi muncul melalui media kaca, kanvas, dan juga batik. Oleh karenanya sangat menarik untuk menyimak sejarah perkembangan seni kaligrafi Islam di Indonesia dari masa ke masa (Ambary, 1998: 45).

Tidak hanya menjadi penanda pada nisan, kaligrafi juga menjadi bagian penting dalam penulisan materi pelajaran proses penyebaran Islam, catatan pribadi, undang-undang, naskah perjanjian resmi dalam bahasa setempat, tulisan pada mata uang logam, stempel, kepala surat, dan sebagainya. Oleh karena itu dalam perkembangannya dikenal huruf Arab yang dipakai dalam bahasa lokal, seperti huruf Arab Melayu dan Arab Jawa atau Arab pegon yang banyak digunakan dalam penulisan kitab-kitab ajar di pesantren di Pulau Jawa, termasuk Pesantren Jawa Barat.

\section{Penyebaran Seni Kaligrafi Islam dan Peran Pesantren di Jawa Barat}


Pesantren yang tersebar di berbagai daerah di Jawa Barat memiliki andil yang besar di dalam menyebarkan seni kaligrafi. Turut sertanya pesantren dalam memberikan saham yang besar dalam penyebarluasan seni kaligrafi pada dasarnya sangat memiliki keterkaitan dengan aktivitas pendidikan yang diselenggarakan di pesantren.

Perlu diketahui bahwa dalam tradisi kehidupan di pesantren, setiap santri yang diam dan belajar di pesantren diajarkan ilmu baca dan tulis Alquran. Mekanisme sistem pendidikan dan pengajaran yang umum berlaku di pesantren biasanya dipraktikkan dengan aktivitas kiyai membacakan kitabkitab kemudian disertai terjemahan lalu diberikan ulasan yang cukup, sementara para santri secara khusus dan patuh memperhatikan, mendengarkan dan menyerap ilmu yang disampaikan oleh para kiyai dalam sebuah pesantren. Di pesantren para santri juga mendengarkan dan menuliskan arti atau terjemahan dari pelajaran yang disampaikan kiyai ke dalam badan tulisan pada kitab. Di sini dengan sendirinya, pelajaran kaligrafi juga diberikan mengiringi pelajaran agama seperti Alquran, Hadits, Fikih, Tauhid, Akhlak dan Tasawuf.

Di sebuah pesantren, tulisan yang diajarkan mula-mula, adalah gaya tulisan yang sangat sederhana, seperti gaya tulisan $R i q^{\prime} i$ atau Kufi yang secara umum condong ke kanan, karena sifatnya penting untuk menunjang santri mencatat pelajaran dari kyai. Kaligrafi dengan gaya tulisan Riq'i memang sederhana. Presisi ukuran panjang-pendek, tinggi-rendah, atau besar-kecil huruf bukan yang utama. Tulisan gaya ini relatif dapat ditulis dengan cepat. Setelah para santri semakin terbiasa dan mahir menulis Arab, langkah berikutnya baru kepada muatan pelajaran khath dengan gaya tulisan yang lebih estetis dan lebih rumit diajarkan. Dengan sudah terbentuknya model pengajaran yang ditemui di pesantren tampak seperti ini, kemudian terjadi 
dalam rentang waktu yang panjang dan berkelanjutan bersamaaan dengan proses penyebaran Islam itu sendiri di wilayah Jawa Barat disadari atau tidak bagaimanapun pesantren telah memiliki andil dalam mengembangkan dunia tulis menulis Arab dan kaligrafi.

Oleh karena itu sejak masuk dan menyebarnya Islam ke wilayah Jawa Barat, seni kaligrafi dapat dipastikan telah berkembang di pesantren. Perlu dikemukakan kehadiran Pesantren Qura di Karawang pada tahun 1418 M yang didirikan Syekh Hasanudin bin Yusuf Sidik dan Pesantren Pasambangan oleh Syekh Datuk Kahfi pada tahun 1420 dapat dipandang sebagai pesantren yang merintis berkembangnya seni kaligrafi di pesantren yang berada di wilayah Jawa Barat. Berdasarkan informasi tersebut, keberadaan Pesantren Quro di Karawang dan Pesantren Pasambangan di Amparan Jati- Cirebon dapat dikatakan sebagai pesantren yang menjadi mata rantai pertama yang berperan dalam proses penyebaran seni kaligrafi Islam ke wilayah Jawa Barat pada abad ke-15.

Pada masa Syarif Hidayatullah/Sunan Gunung Djati ia mendirikan Pesantren Dukuh Sembung-Pasambangan dan Ciptarasa sebagai tempat kegiatan pendidikan. Sejak tahun 1470 M Cirebon telah berkembang sebagai pusat kegiatan penyebaran dan pendidikan seiring dengan hadirnya Syarif Hidayatullah sebagai pemimpin agama dan politik. Pada masa ini seni kaligrafi Islam berkembang dengan pesat. Pesantren Dukuh SembungPasambangan dan Ciptarasa menjadi mata rantai berikutnya yang berperan dalam penyebarluasan kaligrafi Islam seiring dengan proses penyebaran Islam pasca Pesantren Quro di Karawang dan Pesantren Pasambangan di Amparan Jati ( Graaf, 1949: 116-117; Ekadjati, 1984: 91). 
Pada abad ke-17 dan $18 \mathrm{M}$ Pesantren Ciwaringin, Balerante, Buntet, Ciwedus dan Lengkong adalah lima pesantren di wilayah timur yang menjadi mata rantai penyebaran seni kaligrafi ke wilayah Priangan Timur. Kemudian, masih sezaman dengan periode ini, Pesantren Pamijahan Syekh Abdul Muhyi, dan Pesantren Takhasus Jafar Sidiq adalah tiga pesantren pertama di wilayah pedalaman Priangan bagian selatan yang memiliki andil dalam pengembangan kaligrafi pada abad Ke-17 dan ke- 18 M (Asy'ari, 1999: 4; Asy'ari, Wawancara, 30 Januari 2010; Rosidi et al., 2000: 262-283 \& 514-515 ; Mas'udi et al., 1986: 91-92; Ensiklopedi Islam, 2003: 5-8).

Pada Abad ke-19 (1800-1900) penyebaran kaligrafi di wilayah Jawa Barat banyak dilakukan oleh Pesantren Al-Falah-Biru, Sumur Kondang, Keresek, dan Al-Hidayah di Garut; Pesantren Gentur, Kandang Sapi, Darul Falah-Jambudipa di Cianjur, dan Pesantren Asyropudin di Sumedang. Di daerah Banjar Pesantren Minhajul Karomah Cibeunteur layak juga untuk dikemukakan telah berperan di dalamnya, bersama dengan Pesantren Mahmud, Sukafakir, dan Sukamiskin di daerah Bandung (Basri, 1977: 2; Lilis, Wawancara, tanggal 13 Januari 2010; Affandi, Wawancara, tanggal 28 Juli 2011; Munandar, Wawancara, tanggal 12 Pebruari 2010; Komarudin, Wawancara, tanggal 12 Pebruari 2010; Anam, Wawancara, tanggal 12 Pebruari 2010; Sanusi, Wawancara, 30 Juli 2011; Wadud, Wawancara, tanggal 19 Januari 2010; Aziz, Wawancara, tanggal 15 Juli 2011).

Pada awal abad ke-20 sampai dengan dekade keempat dari abad ke-20 (1900-1945) penyebarluasan seni kaligrafi banyak dikembangkan oleh Pesantren Pangkalan, Cipari, dan Darussalam di Garut. Di daerah Majalengka, penyebarluasan seni kaligrafi banyak dilakukan oleh Pesantren Santri Asromo. Sedangkan di Tasikmalaya banyak dilakukan oleh Pesantren 
Kudang, Suryalaya, Cilenga, Cintawana, Miftahul Ulum, Mathlaul Khair, As-Salam, Bahrul Ulum, Sukahideung, Sukamanah, dan Cipasung (Yahya, 2006: 14; Halim, Wawancara, tanggal 14 Januari 2010; lihat juga Siswanto et al., 2005: 8; Hasan, Wawancara, tanggal 18 Januari 2010; Rosidi et al., 2000: 514; At-Tarmizi dan Kalam, 2008: 2-3).

Masih pada periode ini penyebarluasan kaligrafi di daerah Bandung banyak dilakukan Pesantren Al-Bidayah Cangkorah, Al-Asyikin, IslamiyahCijawura, Cikapayang, Sindangsari Al-Jawami, Al-Ittifaq, Pesantren Persis, Palgenep, Hegarmanah, Cigondewah, Sirnamiskin, Sadangsari dan Cijerah di Bandung. Sementara di daerah Ciamis banyak dilakukan oleh Pesantren Darul Ulum, Pesantren Cidewa/Darussalam, Pesantren Al-Qur'an Cijantung, Pesantren Miftahul Hoer, dan Pesantren Al-Fadhiliyah (Petir) ( Mas'udi et al., 1986: 13, 48 \& 66; Hamid, Wawancara, tanggal 2011; Abdullah, Wawancara, tanggal 30 Januari 2010; Mansur, Wawancara, 18 Januari 20110; Haris, Wawancara, tanggal 14 Desember 2011; Solehudin, Wawancara, tanggal 12 Januari 2010).

Untuk di daerah Sukabumi penyebarluasan kaligrafi banyak dilakukan oleh Pesantren Cantayan, Genteng dan Syamsul Ulum Gunung Puyuh Sukabumi. Sementara di daerah Banjar dan Sumedang, banyak dilakukan oleh Pesantren Miftahul Huda Al-Azhar Citangkolo di Banjar dan Pesantren Pagelaran Sumedang-Subang dan Darul Hikmah (Sulasman, 2008: 149; Rohim, Wawancara, tanggal 19 Januari 2010; Muhyidin, Wawancara, tanggal 13 Maret 2010

Saat ini di Jawa Barat sudah banyak bertebaran pesantren. Dari sekian banyak pesantren yang bertebaran tersebut terdapat beberapa pesantren khusus yang mengembangkan seni kaligrafi dengan berbagai corak dan 
modenya yaitu Pesantren At-Tanwiriyah di Cianjur pimpinan K.H. Asep AtTanwir. Kemudian di Ciamis terdapat Pesantren Raudhatul Muta'alimin yang dipimpin K. H. Shofiullah. Selain itu penyebarluasan seni kaligrafi pun didukung oleh berdirinya sebuah lembaga khusus yang bernama Lembaga Kaligrafi (Lemka) yang dipimpin K.H. Siradjudin Ar.

Itulah peran pesantren dalam penyebarluasan seni kaligrafi Islam di Jawa Barat. Akhirnya patut diketahui secara bersama-sama bahwa ada beberapa faktor yang menyebabkan seni kaligrafi Islam berkembang dalam kehidupan pesantren di Jawa Barat. Di antara faktor-faktor itu adalah: pertama, karena besarnya minat, perhatian, dan dukungan yang diberikan kiyai pemimpin/pemilik sebuah pesantren untuk mengembangkan seni kaligrafi. Tanpa adanya minat, perhatian, dan dukungan yang besar dari kiyai pemimpin/pemilik sebuah pesantren sebagai kelompok elit sosio-religious, tidak mungkin seni kaligrafi Islam akan tetap bisa terpelihara di bumi Jawa Barat dan Indonesia ini.

Kedua, masih adanya kegiatan tradisi intelektual yang dilakukan melalui kegiatan pengajian yang berkelanjutan, di mana dalam kegiatan itu proses transmisi dan tranformasi ilmu pengetahuan tetap berjalan, termasuk dalam hal ini di dalam menjaga, memelihara dan melestarikan seni kaligrafi Islam.

Ketiga, seni kaligrafi Islam terus berkembang dalam kehidupan pesantren di Jawa Barat tidak bisa dipisahkan dari peran para santri yang belajar tentang seni kaligrafi pada sebuah pesantren kemudian mereka mengembangkan kembali ilmu yang diperoleh pada saat mendirikan pesantren baru di tempat lain. Mereka ini dapat disebut sebagai "seniman kaligrafi" yang melestarikan seni kaligrafi agar tetap terus lestari dan berkembang. 


\section{PENUTUP}

Demikian peran pesantren dalam penyebarluasan seni kaligrafi di Jawa Barat. Akhirnya dari uraian tersebut dapat disimpulkan:

a. Seni kaligrafi Islam berkembang di Jawa Barat pertama kali bersamaan dengan masuk dan menyebarnya Islam ke wilayah tersebut, yang salah satunya disebarkan melalui institusi pesantren.

b. Ada beberapa faktor yang menyebabkan seni kaligrafi Islam berkembang dalam kehidupan pesantren di Jawa Barat. Di antara faktorfaktor itu adalah: pertama, karena besarnya minat, perhatian, dan dukungan yang diberikan kiyai pemimpin/pemilik sebuah pesantren untuk mengembangkan seni kaligrafi. Kedua, masih adanya kegiatan tradisi intelektual yang dilakukan melalui kegiatan pendidikan melalui pengajian yang berkelanjutan, mulai dari baca dan tulis Alquran, aktivitas kiyai membacakan kitab-kitab yang disertai terjemahan lalu diberikan ulasan yang cukup. Di sini dengan sendirinya, pelajaran kaligrafi juga diberikan mengiringi pelajaran agama.

c. Pesantren memiliki peran di dalam menyebarkan seni kaligrafi Islam, mula-mula dengan mengajarkan gaya tulisan yang sangat sederhana, seperti gaya tulisan $R i q^{\prime} i$ atau Kufi. Tulisan gaya ini relatif dapat ditulis dengan cepat. Setelah para santri semakin terbiasa dan mahir menulis Arab, langkah berikutnya baru kepada muatan pelajaran khath dengan gaya tulisan yang lebih estetis dan lebih rumit diajarkan. Dengan sudah terbentuknya model pengajaran seperti ini, dalam rentang waktu yang panjang dan berkelanjutan pesantren telah memiliki andil dalam mengembangkan dunia tulis menulis Arab dan kaligrafi. 
d. Di antara pesantren di Jawa Barat yang berperan dalam penyebarluasan seni kaligrafi ialah Pesantren Qura di Karawang dan pesantren Pasambangan di Cirebon sejak abad ke-15; Pesantren Ciwaringin, Balerante, Buntet (ketiganya di Cirebon), Ciwedus, Lengkong (keduanya di Kuningan), dan Pesantren Biru (Garut) pada abad Ke-17 dan ke- 18 M. Pada abad ke-19 di antara pesantren yang memiliki andil dalam penyebarluasan seni kaligrafi Islam adalah Pesantren Sumur Kondang dan Keresek di Garut; Pesantren Gentur, Kandang Sapi , dan Darul Falah-Jambudipa di Cianjur; Pesantren Asyropudin di Sumedang; Pesantren Minhajul Karomah di Ciamis; Pesantren Sukamiskin di Bandung. Pada abad ke-20 Pesantren Cipari (Garut); Pesantren Santri Asromo (Majalengka); Pesantren Kudang, Suryalaya, Cilenga, Cintawana, dan Cipasung (Tasikmalaya); Pesantren Sindangsari Al-Jawami, Al-Ittifaq, Pesantren Persis (di Bandung); Pesantren Darul Ulum, Pesantren Cidewa/Darussalam, Pesantren AlQur'an Cijantung di Sukabumi; Pesantren Syamsul Ulum Gunung Puyuh di Sukabumi; Pesantren Miftahul Huda Al-Azhar (BanjarCiamis); Pesantren Pagelaran di Sumedang-Subang; At-Tanwiriyah di Cianjur, dan Raudhatul Muta'alimin adalah sebagian diantara sekian banyak pesantren-pesantren yang memiliki andil dalam penyebarluasan seni kaligrafi Islam pada abad ke-20 sampai dengan sekarang.

\section{DAFTAR PUSTAKA}

Ajip Rosidi et al.

2000 Ensiklopedi Sunda; Alam, Manusia dan Budaya Termasuk Budaya Cirebon dan Betawi. Jakarta : Pustaka Jaya. 
Al-Baba, Kamil

1992 Dinamika Kaligrafi Islam. Terj. D. Srojudin Ar. Jakarta: Darul Ulum Press.

Al-Faruqi, Ismail R dan Al-Faruqi, Louis Lamya

1998 Atlas Budaya Islam. Bandung: Mizan.

Al-Iskandari, Ahmad dan Anami, Musthofa

1961 Al-Wasit fi Al-Adab Al-Arabi wa Tarikihi. Misr: Daar al-Ma'arif.

C. Israr

1985 Dari Teks Klasik Sampai ke Kaligrafi Arab. Jakarta: Yayasan Masagung.

Dewan Redaksi Ensiklopedi Islam

2003 Ensiklopedi Islam, 2003. Jilid IV. Jakarta: Ichtiar Baru van Hoeve.

D. Sirajudin Ar.

1985 Seri Kaligrafi Islam. Jakarta: Pustaka Panjimas.

Edi S. Ekadjati

1984 "Sejarah Sunda" dalam Edi S. Ekadjati (ed.) Masyarakat Sunda dan Kebudayaannya. Jakarta: Girimukti Pasaka. Hlm. 89.

De Graaf, H.J.

1949 Geschiedenis van Indonesie. Bandung: N.V. Uitgeverij W. Van Hoeve$\mathrm{s}^{\prime \prime}$ Gravenhage.

Hasan Basri.

1977 Sejarah Timbulnya Pesantren Keresek. Keresek: Tanpa Penerbit.

Hasan Muarif Ambary

1998 Menemukan Peradaban : Jejak Arkeologis dan Historis Indonesia. Jakarta: Logos Wacana Ilmu Cetakan Ke-1.

H.B. Siswanto, et al.

2005 Satu Abad Pondok Pesantren Suryalaya : Perjalanan dan Pengabdian 19052005. Tasikmalaya: Yayasan Serba Bakti Pondok Pesantren Suryalaya.

Iip D. Yahya

2006 Ajengan Cipasung; Bigrafi K.H. Moh. Ilyas Ruhiat. Yogyakarta: Pustaka Pesantren. 
Masdar F Mas'udi, et al.

1986 Direktori Pesantren. Jakarta: Perhimpunan Pengembangan Pesantren dan Masyarakat.

Obing Asyari

1999 Sejarah Pondok Pesantren dan Perkembangan Agama Islam di Ciwedus Timbang. Kuningan: Yayasan Al-Ikhlas.

Safadi, Yasin Hamid

1979 Islamic Calighraphy. Colorado: Shambala Publication, Inc.

Sartono Kartodirdjo et al.

1976 Sejarah Nasional Indonesia. Jilid III. Jakarta: Departemen Pendidikan dan Kebudayaan.

Sulasman

2008 "K.H. Ahmad Sanusi: Berjuang dari Pesantren hingga Parlemen" dalam Irfan Safrudin (Ed.), Ulama-ulama Perintis: Biografi Pemikiran dan Keteladanan. Bandung : MUI Kota Bandung.

Triyanto

1988 Mengenal Bentuk-bentuk Kaligrafi Arab. Media FPBS IKIP Semarang.

Yoga Ad. At-Tarmizi dan M. Yajid Kalam

1999 K.H. Moh. Ilyas Ruhiat Ajengan Santun dari Cipasung; Membedah Sejarah Hidup dan Pemikiran Islam Keumatan. Bandung: Remaja Rosda Karya.

\section{Wawancara}

Abdul Aziz (60 Tahun)

Pimpinan Pesantren Sukamiskin Bandung. Wawancara, tanggal 15 Juli 2011 di Bandung.

Abdul Halim ( \pm 54 Tahun) 
Pimpinan Pesantren Al-Bayinah sekaligus Ketua MUI Garut. Ia merupakan anak Prof. K.H. Anwar Musaddad dan menantu K.H. Yusuf Taujiri. Wawancara, tanggal 14 Januari 2010 di Garut.

Abdullah Syifaa (65 Tahun)

Pimpinan Pesantren Buntet Cirebon. Wawancara, tanggal 30 Januari 2010 di Cirebon.

Anwar Sanusi (55 Tahun)

Pimpinan Pesantren Asyropudin Sumedang. Wawancara, tanggal 30 Juli 2011.

Atam Rustam ( \pm 52 Tahun)

Cucu dari K.H. Zaenal Mustofa, yang sekarang menjabat sebagai Kepala MAN Sukamanah Tasikmalaya. Wawancara, tanggal 18 Januari 2010 di Tasikmalaya.

Buldan Komarudin (60 Tahun)

Pimpinan Pondok Pesantren Darul Falah Jambudipa. Wawancara, tanggal 12 Pebruari 2010 di Cianjur.

Dandy Sobron Muhyidin (33 Tahun)

Pimpinan Pesantren Pagelaran 3, anak K.H. Oom Abdul Qoyim Muhyidin dan cucu dari K.H. Muhyidin. Wawancara, tanggal 13 Maret 2010 di Subang.

Dudung Abdul Wadud (65 Tahun)

Cucu dari pendiri Pondok Pesantren Cibeunter dan sekarang merupakan pimpinan kelima dari Pesantren Cibeunteur Kota Banjar. Wawancara tanggal 19 Januari 2010 di Banjar.

Eded Hasan ( \pm 63 Tahun)

Cucu dari anak pertama pendiri Pesantren Cintawana. Wawancara. tanggal 18 Januari 2010 di Tasikmalaya.

Fadlil Munawar Mansur ( \pm 48 Tahun) 
Salah seorang pimpinan Pesantren Darussalam Ciamis. K.H. Fadlil Munawar Mansur adalah anak pertama K.H. Irfan Hilmy. Wawancara, tanggal 19 Pebruari 2010 di Ciamis.

Iir Abdul Haris (38 tahun)

Pimpinan Pesantren Cijantung Ciamis, dan cucu-menantu K.H. Siradj, pendiri Pesantren Cijantung. Wawancara, tanggal 14 Desember 2011 di Bandung

Lilis Abdul Halim, Hj. ( \pm 48 Tahun $)$

Anak dari K.H. Yusuf Taujiri dan isteri dari K.H. Abdul Halim. Wawancara, tanggal 14 Januari 2010 di Garut.

Lilis Hasan Basri, Hj. ( \pm 60 Tahun)

Isteri dari K.H. Hasan Basri (alm.) pimpinan kelima dari Pesantren Keresek Garut. Wawancara, tanggal 13 Januari 2010 di Garut.

Muhammad Abdullah ( \pm 66 Tahun)

Anak ke delapan K.H. Ahmad Panuju, pimpinan Pesantren Darul Ulum. Wawancara, tanggal 30 Januari 2010 di Ciamis.

Munandar, H. (40 Tahun)

Anak dari K.H. Hidayat, sekaligus cucu dari K.H. Opo Mustofa, pendiri Pesantren Kandang Sapi. Wawancara, tanggal 12 Pebruari 2010 di Cianjur.

Munawir Abdul Rohim (54 Tahun)

Pimpinan Pesantren Miftahul Huda Al-Azhar Citangkolong Banjar. Wawancara, tanggal 19 Januari 2010 di Banjar.

Obing Asyari (82 Tahun)

Pimpinan Pesantren Ciwedus. Wawancara, tanggal 30 Januari 2010 di Kuningan.

Uus Usman Affandi (35 Tahun)

Pimpinan Pesantren Keresek Garut. Wawancara, tanggal 28 Juli 2011 di Garut 
